\title{
Product Market Competition And Analysts' Forecasting Properties: Evidence From Korea
}

Jaehong Lee, Sangmyung University, South Korea

Kyoungwon Mo, Chung-Ang University, South Korea

\begin{abstract}
In this paper, we examine the association between product market competition and financial analysts' forecasting properties in a sample of 76,621 analyst-firm-year observations in South Korea between 2000 and 2014. Using the Herfindahl-Hirschman Index to proxy for product market competition, we document that financial analysts are likely to issue less accurate and more optimistic forecasts in highly competitive product markets. In addition, we find that analysts' reports show more optimism in stock recommendations in firms with high market competition.
\end{abstract}

Keywords: Product Market Competition; Analysts' Forecast Accuracy; Analysts’ Forecast Optimism; Analysts' Stock Recommendations Optimism

\section{INTRODUCTION}

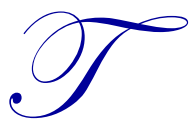

his study investigates the effects of disclosure environments induced by product market competition on the properties of analysts' reports. Several researchers have attempted to provide substantial evidence for the influence of product market competition in corporate information environments based on managers' disclosure policies with consideration of the proprietary costs for firms. However, the existing research outcomes regarding the link between product market competition and corporate information environments are mixed (Beyer, Cohen, Lys \& Walther, 2010; Berger, 2011). One line of research describes that product market competition is a market force to alleviate agency costs (Hart, 1983; Schmidt, 1997; Baggs \& Bettignies, 2007). Competition is generally thought to limit managerial opportunism when earnings are reported, thereby improving the quality of the information environment (Laksmana \& Yang, 2012). Moreover, Stivers (2004) reports that revelation of proprietary information strengthens market competition. This reduces information asymmetry costs, allowing firms to obtain more favorable financing. Product market competition also suppresses opportunities for expropriation by managers; therefore, firms in highly competitive markets are expected to have transparent information environments.

On the other hand, some studies suggest a negative relationship between product market competition and corporate information environments. Through competition, firms are able to assess managers' performance compared with their competitors (Vickers, 1995; Meyer \& Vickers, 1997) and competition also intensifies managers' career concerns (Feriozzi, 2011). In a similar vein, DeFond and Park (1999) find that high competitive industries show more frequent chief executive officer (CEO) turnover compared to less competitive industries. Thus, it is reasonable to assume that managers in more competitive markets have a tendency to withhold information, and thus leads to an environment in which less informative disclosure is common; in these markets, business strategies and corporate profits are highly affected by the actions of competitors. In addition, the link between competition and the information environment may be associated with the innovation strategy in an industry. Since innovative firms are associated with information complexity, the implications of their information are difficult to assess. Thus, we can reason that analysts may have greater difficulties in proper assessment and prediction of firm performance in competitive industries.

We first investigate the relation between product market competition and the accuracy of analysts' forecasts. We find a positive association between product market competition and less accurate earnings forecasts, as measured by relative measures of analysts' forecast accuracy (Hong \& Kubik, 2003; Cowen, Groysberg \& Healy, 2006; Bae, Stulz 
$\&$ Tan, 2008). The results do not change in complementary tests using Fama-Macbeth estimation, which considers potential bias problems caused by data dependence. We then examine whether bias occurs in analysts' earnings forecasts for firms in competitive product markets. We find significant forecast optimism in analysts' forecasts in competitive product markets after controlling for relevant firm and year, as well as analyst characteristics. Finally, we investigate optimism in analysts' stock recommendations for firms in competitive product markets. We report a stronger relationship between high competition and optimistic bias in stock recommendations. This result suggests that product market competition intensifies managerial tendencies withholding firm-specific information, thereby deteriorating the information environment in which analysts must work by increasing optimism in stock recommendations.

This study makes substantial contributions to the existing literature. First, prior accounting literature reports mixed evidence on the relationship between product market competition and corporate information environments. In addition, we incorporate additional properties of analysts' reports to provide a more comprehensive, in-depth analysis. Second, given that analysts' forecasting activities play an integral role in investors' asset pricing, it is important to understand the effect of product market competition on analysts' reports. In line with this, our results have implications for investors who use analysts' reports for firm valuation since more accurate and pessimistic forecasting is associated with more precise valuations. Finally, from another perspective, our study is also related to literature on financial analysts' compensation. Our findings suggest the notion that competition creates incentives for analysts' brokerage house to compensate based on relative forecast accuracy by incorporating the difference in information complexity of different industries.

The rest of this paper proceeds as follows. Section II provides the prior research and develops the hypotheses. Section III explains the research design and the data. Section IV presents the results of the empirical analysis, and Section V summarizes and concludes the paper.

\section{RELATED RESEARCH AND HYPOTHESIS DEVELOPMENT}

\section{Product Market Competition}

In the lack of associated costs of disclosure, firms release all value-relevant information, both public and private, to investors and managers are unable to withhold firm-specific information due to the problem of adverse selection (Grossman, 1981; Milgrom, 1981). However, if we consider the disclosure costs associated with releasing private information such as proprietary costs, only partial-disclosure equilibrium might be established. This is because naïve investors are unable to determine whether the withholding of information is due to avoiding the bad news or to the costs related to disclosing good news (Verrecchia, 1983). Since the demand for corporate information comes from a variety of market participants such as shareholders, creditor, employees, and monitoring agencies, it is plausible that the disclosure of all value-relevant information has different impacts on these parties. For instance, information about new products may be relevant to its stakeholders and the future prospects of a firm, but at the same time, it might also reveal firm-specific strategies to competitors, thereby damaging firms' competitive advantages. These negative effects are referred to as proprietary costs, and such costs related to competitors. Research on product market competition provides mixed results as to whether product market competition encourages or discourages disclosure of corporate value-relevant information.

Prior studies on product market competition and disclosure environments report a positive side of competition on the quality of disclosure, demonstrating that competition plays disciplinary mechanism which enforces managements to exercise their best efforts not to fail in the competition. According to Dhaliwal, Huang, Khurana \& Pereira (2012), high competition in product market leads to more timely recognition of losses in accounting earnings; Darrough and Stoughton (1990) document that higher competitive market where potential competitors can enter the market with lower entry costs induces greater disclosure of bad news for firms by discouraging additional entry of rivals to the existing market; Laksmana and Yang (2012) find that both accruals-based and real activity-based earnings management are less dominant among firms in more competitive markets than among those in less competitive markets; Li, Lundholm \& Minnis (2013) demonstrates a positive relationship between the degree of competition and industry pervasiveness of management forecasts; and Cheng, Man and Yi (2013) find that product market competition is positively associated with various earnings attributes. 
In another stream of research on product market competition, a negative association between competition and disclosure environment has been demonstrated. Li et al. (2013) shows that when market competition among industries is imperfect, the quality of management forecasts is lower. Moreover, Gertner, Gibbons \& Scharfstein (1988) and Verrecchia and Weber (2006) report a negative association between firms within more competitive industries and the level of disclosure, supporting the notion of proprietary costs which might incur when competitors get the information. Similarly, Wagenhofer (1990) adds that greater product market competition constrains disclosure from mature competitors as well as potential entrants. In a theoretical context, competition may play a role in accelerating the manipulation of earnings to win in the competition, especially for firms that underperform compared to their competitors (Markarian \& Santalo, 2014). Regarding equity markets, highly competitive firms tend to have more volatile idiosyncratic returns, allowing higher risk-adjusted returns for the informed traders (Gaspar \& Massa, 2006; Hou \& Robinson, 2006; Irvine \& Pontiff, 2009).

\section{Product Market Competition and Properties of Analysts' Forecasts}

Financial analysts' reports are the final results that include the collection, evaluation, and dissemination of information regarding firms' prospects. Throughout this process, analysts and managers participate in interaction by giving and taking information. If managers want to meet analysts' forecasts, they can guide analysts in order to downward their expectation. However, this raises the question whether managerial guidance affects analysts' forecasting activities inappropriately.

In the presence of product market competition, managers' guidance can improve transparency by increasing disclosure, which facilitates tailoring of their product offerings. Prior literature finds that more competitive industries are more inclined to disclose segment information than less competitive industries (Harris, 1998; Hayes \& Lundholm, 1996). In addition, Stivers (2004) shows the positive relationship between competition and the degree of revelation on proprietary information. The author claims that in competitive product markets with a large number of competitors, at least one firm is liable to release its information, which leads to others doing so; thus, market participants activate the process of disclosure. This unraveling process eventually leads to full disclosure along with increase in the number of firms in the product market.

Another incentive for revealing proprietary information is to reduce the costs of information asymmetry, for example, by obtaining external financing at a lower cost of capital. Likewise, Hoberg and Phillips (2010) find a negative association between competition and cost for gathering firm-specific information. They suggest that investors in competitive markets do not fully incorporate the negative externalities of market competition with regard to cash flows and stock returns.

Another plausible link is associated with agency problems. According to literature, market competition plays an important disciplining role for managers to work harder to satisfy the interest of outside shareholders (Allen \& Gale, 2000; Giroud \& Mueller, 2010). Thus, managers can attempt to maximize value or manage costs effectively and efficiently in order to mitigate agency costs, resulting in a more transparent disclosure environment.

On the other hand, managers are sometimes hesitant to disclose value-relevant information. For example, prior studies report that under intense competition, managers may be reluctant to release significant information to minimize proprietary costs which might incur when rivals get the information (Verrecchia, 1983; Clinch \& Verrecchia, 1997). In addition, there is a study to report a positive link between product market competition and disclosure environments with regard to the degree of innovation within industries (Nickell, 1996). Similarly, Hou and Robinson (2006) find that innovative firms in highly competitive markets entail more risk due to inherent volatility within innovation. Innovative assets also include more complex information compared to other types of assets in the following reasons: inherent uncertainty about the capitalization of innovative products, ambiguous property rights regarding the assets, and the absence of active markets and appropriate valuation for most innovative products. Thus, high information complexity related to innovation activities may increase the difficulty for stakeholders assessing the contribution of innovative activities to the firm's future earnings, thereby complicating analysts' forecasting tasks.

Overall, many studies have demonstrated that product market competition in a given industry influences the corporate disclosure strategy. Therefore, product market competition contributes to forming corporate disclosure environments, 
which in turn affects analysts' forecasting environment. However, studies on product market competition do not provide consistent results on the relationship between product market competition and analysts' forecasting activities. The inconsistent results of previous studies with regard to the degree of information disclosure in competitive product markets raise an interesting empirical question: do analysts' forecasts affect the quality of performance for firms in more competitive product markets?

Analysts' Forecast Accuracy

Brown (1993) examines the relations between the accuracy of an analyst's forecast and complexity associated with making forecasts. They provide evidence that as long as firms in competitive product markets provide accurate information about future earnings, analysts' forecast accuracy will increase with the informativeness of managers' disclosure policies (which is influenced by the degree of market competition). However, previous evidence on potential relation between product market competition and disclosure of information in competitive industries is mixed. A potential explanation for these mixed results is because the measure of analysts' forecast accuracy only compares analysts' forecasts with actual reported earnings. These measures of absolute forecast accuracy are strongly affected by whether earnings are particularly hard to forecast due to market competition.

Each individual analyst is situated and performs differently compared to other analysts, thus providing greater difference in contents of analyst's report. Specifically, legal and financial reporting environment in which he or she operates (Barniv, Myring \& Thomas, 2005), the environment of the individual workplace (Jacob, Lys \& Neale, 1999), and his or her innate ability and firm-specific experience (Clement, 1999) may produce difference among analysts. In this reason, product market competition may only explain some parts of the differences in analysts' forecast accuracy. Thus, the inconsistent results of competition on analyst forecast accuracy in literature could be attributable to the measurement errors of absolute forecast accuracy (Barniv et al., 2005; Jacob et al., 1999; Clement, 1999; Shon \& Shin, 2014). To alleviate this problem, this study employs relative forecast accuracy that includes a comparison among peer analysts. As such, considering the ongoing debate on the relation between product market competition and relative forecast accuracy, the first non-directional hypothesis is therefore as follows (stated in the null form).

H1: Product market competition is not associated with relative analysts' forecast accuracy.

\section{Analysts' Forecast Optimism}

Prior studies shows that analysts issue optimistic forecasts in analysts' reports in order to increase economic performance which is largely related to trading volume and investment banking (Ackert \& Athanassakos, 1997; Das, Levine \& Sivaramakrishnan, 1998). In other words, uncertainty in the information environment increases optimism in analysts' reports to curry favor with managers and to achieve non-public information about the firm (Huberts \& Fuller, 1995; Ackert \& Athanassakos, 1997; Das et al., 1998; Lim, 2001). This expectation is labeled "the managementrelations hypothesis". According to this hypothesis, analysts tend to issue more optimistic forecasts in order to expand the amount, period, and type of information they receive from managers in competitive product markets.

By contrast, Hart (1983) and Baggs and Bettignies (2007) assert that product market competition is a market force mitigating agency problems. In terms of external governance mechanisms, competition constrains management opportunism in reporting operating performance (Laksmana \& Yang, 2012). Similarly, Cheng et al. (2013) find that product market competition is positively associated with various earnings attributes. Taken together, these arguments indicate that firms in markets with high competition may have less complex earnings predictability and less optimistic analysts' forecasts.

Given these opposing predictions of the relation between product market competition and optimism in analysts' forecasts, it is an empirical question whether analysts' forecasts show more optimism under competitive circumstances. To address this issue, we propose the non-directional hypothesis as follows (stated in the null form):

H2: Product market competition is not associated with analysts' forecast optimism. 


\section{Analysts' Recommendation Optimism}

While analysts' earnings forecasts focus on providing information of future cash flows to compute stock valuations by reflecting quantitative aspects, analysts' stock recommendations reflect qualitative aspects of reports by showing their own assessment through buy/sell opinions (Cowles, 1933; Bidwell, 1977; Womack, 1996). Prior studies demonstrate that earnings are not sufficient to determine the stock valuation (Hayn, 1995; Barth et al., 1998). Likewise, Schipper (1991) also argues that analysts' forecasted earnings are not final products but intermediate medium that requires more input in producing a final product. Womack (1996) suggests that stock recommendations can be analysts' own opinions on the current stock price based on the publicly available information. Their opinions on the relative degree of undervaluation or overvaluation indicate the inaccuracy of current stock price. Therefore, recommendations are more indicative of whether the stock is mispriced due to the investors' misinterpretation of previously released information.

According to the literature, analysts' promotions and job terminations may affect their forecasting ability, as measured by past forecast accuracy (Stickel, 1992; Mikhail, Walther \& Willis, 1999). Considering analysts' reliance on material public information to issue recommendations (Stickel, 1989; Ivkovic \& Jegadeesh, 2004), analysts who have performed better in forecasting and choosing stocks may also have greater expertise in analyzing the value relevance of public information.

Insofar as product market competition takes a crucial role for the efficient allocation of resources and disciplinary mechanism to reduce managerial opportunism, competition is expected to enhance the quality of public information. In this circumstance, financial analysts may be able to exercise greater objectivity in evaluating available information, which may enable them to develop less optimistic recommendations. On the other hand, under high competition, managers may have a tendency to withhold information for fear of proprietary costs. In response to managers' disclosure policies, therefore, analysts may issue optimistic stock recommendations (upward bias) in order to maintain investment banking business and acquire trading commissions through close access to management (Francis, Hanna \& Philbrick, 1997; Lin \& McNichols, 1998; Irvine, 2004).

Thus, the directional association between product market competition and analysts' optimism in stock recommendation is an empirical question. Even though substantial papers show bias in analysts' stock recommendations (Abarbanell, Lanen \& Verrecchia, 1995; Lin \& McNichols, 1998; McNichols \& O’Brien, 1997), none of these papers directly examines the relationship between product market competition and optimism in stock recommendations. Following these arguments, we propose the following null hypothesis:

H3: Product market competition is not associated with analysts' stock recommendation optimism.

\section{RESEARCH DESIGN AND SAMPLE}

\section{Analysts' Forecast Accuracy}

We use two measures of analysts' forecast accuracy. The first measure is called "absolute analysts' forecast accuracy" and it is widely employed in prior studies (Loh \& Mian, 2006; Sohn \& Shin, 2014). The second accuracy measure is termed "relative analysts' forecast accuracy", and it controls for analysts' accuracy ranking and the degree of complexity in analysts' forecasts (Hong, Kubik \& Solomon, 2000, Hong \& Kubik, 2003, Cowen et al., 2006). The difference between two measures is in how to define analyst $i$ 's forecast accuracy reporting of firm $j$ 's earnings per share (EPS) for period $t, \mathrm{AFA}_{i j t}$. More clearly, we measure the first measure of absolute analysts' forecast accuracy $\left(\mathrm{AAFA}_{i j t}\right.$ ) by the negative value of the absolute value of the difference between the most recent individual analyst $(i)$ 's EPS forecast for firm $j\left(\right.$ FEPS $\left._{i j t}\right)$ and the actual EPS of firm $j$ in year $t\left(\right.$ AEPS $\left._{j t}\right)$, and we standardized the absolute value of the difference by the stock price at year-end $\left(\mathrm{P}_{j}\right)$. By multiplying the negative one, we can interpret an increase in forecast accuracy simply using this measure.

$$
A A F A_{i j t}=(-1) \times \frac{\left|F E P S_{i j t}-A E P S_{j t}\right|}{P_{j}}
$$


Our second measure of relative analysts' forecast accuracy, which controls for analysts' accuracy ranking and forecasting complexity, defines RAFA $\mathrm{A}_{i j t}$ as

$$
\begin{aligned}
& R A F A_{i j t}=100-\left[\frac{\text { Rank }_{i j t}-1}{A F_{j t}-1}\right] * 100 \\
& \text { RAFA }_{\mathrm{ijt}}=100-\left[\frac{\text { Rank }_{\mathrm{ijt}} \mathrm{t}^{-1}}{\text { Analystfollowing }_{\mathrm{jt}}-1}\right] * 100
\end{aligned}
$$

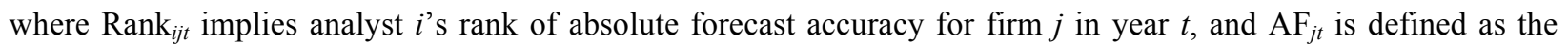
number of analysts following firm $j$ in year $t$ by issuing earnings forecasts for firm $j$. To calculate Rank $i j t$, we basically employ the absolute analyst's forecast accuracy for firm $j$ in year $t$, and then we determine the rank of each analyst relative to all other analysts following the firm $j$. If there are multiple analysts' forecasts for firm $j$ in year $t$, the nearest forecast to earnings announcement date is adopted. The measure of the relative forecast accuracy considers the differences in each analyst's following across firms and years, and it ranges from 0 to 100 percent, meaning that the bigger the number the more accurate it is. In this manner, higher relative forecast accuracy is interpreted as a more accurate analyst's forecast relative to other analysts' forecasts for firm $j$ in year $t$.

\section{Earnings Forecast Optimism}

We use a measure of earnings forecast optimism according to the method of Cowen et al. (2006). This measure is based on the idea that compares the optimism of individual analyst's forecast with those of all other analysts following for firm $j$ in year $t$ in a forecasting horizon. By doing this, we can control for any differences across firms and years that influence optimistic bias in analysts' forecast. As such, we measure the relative forecast optimism in the following equation:

$$
\text { Relative Forecast Optimism } \text { ijt }_{1}=\frac{F E P S_{i j t}-\operatorname{mean}\left(F E P S_{j t}\right)}{\operatorname{STD}\left(F E P S_{\mathrm{jt}}\right)}
$$

where FEPS $_{i j t}$ is the most recent individual analyst (i)'s EPS forecast for firm $j$ in year $t$. Then, we deduct average value of FEPS ${ }_{i j t}$ from the FEPS Fijt $_{\text {. This process allows us to compare FEPS }}$ with the average forecasts for all other analysts following firm $j$ in year $t$ considering the forecast horizon. For standardization of this measure, relative forecast optimism is divided by the standard deviation of all the analysts' EPS forecasts for firm $j$ in year $t$.

\section{Product Market Competition}

We use a measure of Herfindahl-Hirschman Index (HHI) as a proxy for product market competition. This measure is calculated by the sum of the squares of the industry-level market shares of the firms' sales at year-end.

$$
H H I_{k}=\sum_{j=1}^{n}\left(\frac{\text { Sales }_{j k}}{\sum_{j=1}^{n} \text { Sales }_{j k}}\right)^{2}
$$

where Sales $j$ is defined as the market share of sales for firm $j$ in industry $k$, and $\mathrm{n}$ counts the number of firms including in industry $k$ at year-end. The value of this measure decreases along with the number of competitors and increases with the variability in market share of firm within the industry. In other words, HHI is inversely affected by the product market competition. For the convenience of interpretation, we set a dummy variable that takes a value of one for the case where the value of $\mathrm{HHI}$ is smaller than the median, and 0 otherwise.

\section{Empirical Models}

We examine the association between the impact of product market competition and analysts' forecast accuracy in our testing of hypothesis 1 . Both the ordinary least squares (OLS) regressions with clustered standard errors at the firm level (Petersen, 2009) and the Fama-MacBeth regressions are used to test Hypothesis 1. 


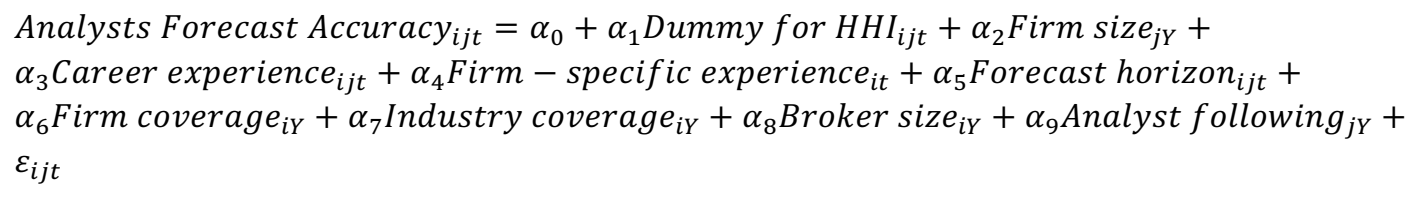

Following Lim and Jung (2012), Analysts' Forecast Accuracy ${ }_{i j t}$ is measured as either the relative or absolute accuracy of analysts' EPS forecasts. Dummy for $H H I_{i j t}$ is a dummy variable that equals to one if analyst $i$ EPS forecasts for firm $j$ in a highly competitive market in $t$, and zero otherwise. The significant positive (negative) coefficient of Dummy for $H H I\left(\alpha_{1}\right)$ interprets that product market competition is positively (negatively) associated with increasing analysts' forecast accuracy. Firm size $e_{Y Y}$ is measured by the $\log$ of market value for firm $j$ in year Y. Firmsize is included to control for the amount of public information leading to more accurate forecasts (Bae et al., 2008). We control for the experience of analysts with a firm as career experience and firm-specific experience. Career experience $_{i t}$ indicates analysts' expertise, begins analyst $i$ 's first forecast that is reported in the DataguidePro database. Firm-specific experience $_{i j t}$ means analysts' firm-specific expertise, begins analyst $i$ 's first forecast for a particular firm $j$ in the database. Forecast horizon $i j t$ is measured as the period between the date of forecast in year $t$ and the actual earnings announcement date in year t. By including the forecast horizon, we can control the analyst workload or task complexity, which can affect forecast accuracy (Clement, 1999; Jacob et al., 1999). We also control for the number of firms covered by any given analyst. Moreover, we control for the degree of specialization by including the number of industries covered by an analyst and for possible advantages in forecasting due to the size of the security firm by including broker size. Specifically, Firm coverage $e_{i Y}$ is the number of firms analyst $i$ follows during the year $Y$; Industry coverage $_{i Y}$ is the number of industries analyst $i$ follows during the year $Y$; Broker size $e_{i Y}$ is the number of analysts who work in same securities firms as measured at the end of year $Y$. Finally, Analyst following is calculated by the number of analysts following a particular firm $j$ at the end of year $Y$ (Gu \& Xue, 2008).

Next, we test the second hypothesis using the following equation.

$$
\begin{aligned}
& \text { Analysts Forecasts Optimism } \text { Opt }_{1}=\alpha_{0}+\alpha_{1} \text { Dummy for HHI }_{i j t}+\alpha_{2} \text { Firm size }_{j Y}+ \\
& \alpha_{3} \text { Career experience }_{i j t}+\alpha_{4} \text { Firm }- \text { specific experience }_{i t}+\alpha_{5} \text { Forecast horizon }_{i j t}+ \\
& \alpha_{6} \text { Firm coverage }_{i Y}+\alpha_{7} \text { Industry coverage }_{i Y}+\alpha_{8} \text { Broker size }_{i Y}+\alpha_{9} \text { Analyst following }_{j Y}+ \\
& e_{i j t}
\end{aligned}
$$

The definition of variables is identical with that is used in equation (5), except that the dependent variable is analysts' forecasts optimism. We also use both OLS regressions with clustered standard errors at firm level and Fama-MacBeth regressions simultaneously. If the coefficient of the Dummy for $H H I\left(\alpha_{1}\right)$ in equation (6) is significantly positive (negative), product market competition would be positively (negatively) related to increasing optimism in analysts' forecasts.

In our third regression analysis, we regress analysts' recommendation optimism against product market competition following the protocol in Cowen et al. (2006). Analysts' stock recommendations are shown in the form of a discrete and ordinal expression, thus violating the basic assumptions of OLS. Instead, an ordered logit regression is used to investigate optimism in stock recommendation, as follows (Cowen et al., 2006; Kolasinski \& Kothari, 2008).

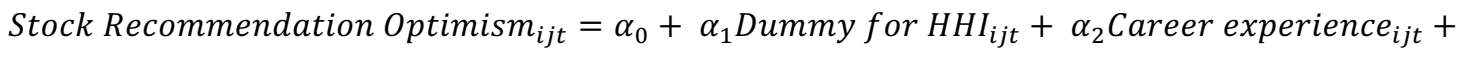

$$
\begin{aligned}
& \alpha_{3} \text { Firm - specific experience } i_{i j t}+\alpha_{4} \text { Forecast horizon }_{i j t}+\alpha_{5} \text { Absolute Forecast accuracy }_{i j t}+ \\
& \alpha_{6} \text { Number of Strong Buy }{ }_{i j t}+\alpha_{7} \text { Number of Buy }{ }_{i j t}+\alpha_{8} \text { Number of Hold }{ }_{i j t}+ \\
& \alpha_{9} \text { Number of Underperform }{ }_{i j t}+\alpha_{10} \text { Number of Sell }_{i j t}+e_{i j t}
\end{aligned}
$$

Stock recommendations are consisted of 5 categories. Specifically, 'Strong Buy' opinion for a stock recommendation is coded as 4; 'Buy' opinion is coded as 3; 'Hold' opinion is coded as 2; 'Under-perform' opinion is coded as 1; Finally, 0 is coded for a 'Sell' opinion. In addition, absolute forecast accuracy is included to control for the relation between forecast accuracy and stock recommendations (Hong \& Kubik, 2003). The significantly positive (negative) coefficient of $\alpha_{1}$ means that analysts' stock recommendations for firms in highly competitive industries are more (less) 
optimistic than those for firms in less competitive industries. The definitions of all other variables are followed in equation (5).

\section{Sample Selection}

Our analysts' EPS forecasts and stock recommendations data is extracted from the DataguidePro database for companies listed in the KSE (Korean Stock Exchange) and the KOSDAQ (Korean Securities Dealers Automated Quotation). For each forecast and recommendation, we track the related company name, the issuance dates of the forecast and recommendation, the code of the analyst and security firm based on its textual data, and actual EPS $_{j t}$ for firm $j$ in year $t$. To identify actual earnings announcement dates for firm $j$ in year $t$, we also use the TS-2000 database.

This procedure results in 1,165,074 analyst-firm-year observations. Then we exclude forecasts without actual earnings announcement dates to identify the most recent stock recommendations and for calculating forecast horizons. We also delete any additional analyst-firm-year level observations that do not meet the following criteria: (1) the most nearest EPS forecasts to the actual announcement date for firm $j$ in year $t$ to alleviate concern about dependencies among recommendations, (2) firms should be followed by at least two analysts to estimate relative forecast accuracy and optimism, (3) forecasts for which the Korea Standard Industry Code (KSIC) codes of forecasted firms can be traced, and (4) forecasts and recommendations for which the values for accuracy and optimism are not missing and data for all control variables are available. In total, 76,621 analyst-firm-year observations are identified between January 1 , 2000 and December 31, 2014 as outlined in Table 1.

Table 1. Sample Selection Procedure

\begin{tabular}{l|r}
\hline All analysts' EPS forecasts in DataguidePro from January 1, 2000 to December 31, 2014 & Number of forecasts \\
\hline Less: Forecasts without actual earnings reporting dates & $1,165,074$ \\
\hline Less: No most recent forecast prior to actual earnings reporting date & $(97,289)$ \\
\hline Less: Forecasts for firms followed by less than two analysts & $(974,327)$ \\
\hline Less: Forecasts without KSIC codes & $(13,423)$ \\
\hline Less: Forecasts without control variables & $(549)$ \\
\hline Final sample & 76,621 \\
\hline
\end{tabular}

\section{RESULTS OF THE EMPIRICAL ANALYSIS}

\section{Sample Distribution}

Table 2 presents the summary statistics of analysts' EPS forecasts sample by year. Panel A represents a sharp rise in the number of forecasts in 2001, a similar number of forecasts between 2001 and 2011, a decrease in 2012, and consistent increases by approximately $4 \%$ every year after 2013 . The pattern seems to be quite evenly distributed by year, with no sign of symmetry in the time-series pattern in analysts' forecasts. Panel B provides the industry classification of analysts' target firms based on the KSIC according to sections. The most frequent industry is manufacturing $(n=41,884,54.66 \%)$, followed by those in the professional, scientific, and technical areas $(n=9,145$, $11.94 \%)$ and those in information and communications $(n=7,848,10.24 \%)$. In addition, the most competitive industry with the lowest value of HHI (0.07) is construction (ranking: 1). The most competitive industries are the financial and insurance industries $(\mathrm{HHI}=0.10$, Rank $=2)$ and information and communications $(\mathrm{HHI}=0.17$, Rank $=3$ ). 
Table 2. Sample Distribution

\begin{tabular}{c|c|c}
\hline Panel A. Distribution by year & Number of forecasts & Percentage (\%) \\
\hline Year & 1,960 & 2.56 \\
\hline 2000 & 5,959 & 7.78 \\
\hline 2001 & 6,584 & 8.59 \\
\hline 2002 & 5,964 & 7.78 \\
\hline 2003 & 5,953 & 7.77 \\
\hline 2004 & 6,372 & 8.32 \\
\hline 2005 & 5,613 & 7.33 \\
\hline 2006 & 6,148 & 8.02 \\
\hline 2007 & 4,834 & 6.31 \\
\hline 2008 & 5,919 & 7.73 \\
\hline 2009 & 5,735 & 7.48 \\
\hline 2010 & 5,780 & 7.54 \\
\hline 2011 & 3,043 & 3.97 \\
\hline 2012 & 3,448 & 4.50 \\
\hline 2013 & 3,309 & 4.32 \\
\hline
\end{tabular}

Panel B. Distribution by industry

\begin{tabular}{|c|c|c|c|c|}
\hline Industry & $\begin{array}{l}\text { Number of } \\
\text { forecasts }\end{array}$ & Percentage $(\%)$ & HHI & Rank \\
\hline Construction & 2,746 & 3.58 & 0.07 & 1 \\
\hline Education & 492 & 0.64 & 0.37 & 10 \\
\hline Financial and Insurance Activities & 6,050 & 7.90 & 0.10 & 2 \\
\hline Agriculture, Forestry, and Fishing & 14 & 0.02 & 0.38 & 12 \\
\hline Wholesale and Retail Trade & 5,289 & 6.90 & 0.19 & 4 \\
\hline Real Estate Activities and Renting and Leasing & 86 & 0.11 & 0.37 & 11 \\
\hline $\begin{array}{l}\text { Business Facilities Management and Business Support } \\
\text { Services }\end{array}$ & 600 & 0.78 & 0.23 & 7 \\
\hline Arts, Sports, and Recreation-Related Services & 387 & 0.51 & 0.36 & 9 \\
\hline Transportation & 977 & 1.28 & 0.45 & 14 \\
\hline Electricity, Gas, Steam, and Water Supply & 1,099 & 1.43 & 0.42 & 13 \\
\hline Professional, Scientific, and Technical Activities & 9,145 & 11.94 & 0.20 & 6 \\
\hline Manufacturing & 41,884 & 54.66 & 0.20 & 5 \\
\hline Information and Communications & 7,848 & 10.24 & 0.17 & 3 \\
\hline $\begin{array}{l}\text { Sewerage, Waste Management, Materials Recovery, and } \\
\text { Remediation Activities }\end{array}$ & 4 & 0.01 & 0.30 & 8 \\
\hline Total & 76,621 & & & \\
\hline
\end{tabular}

\section{Univariate Analysis}

Table 3 delivers the descriptive statistics in our analysis. The first column of Table 3 lists descriptive statistics for the whole sample. The mean (median) value for Relative Analysts' Forecast Accuracy is 47.996 (50.000), which is quite similar to the mean of 49.860 reported in Lim and Jung (2012). The mean value for Absolute Analysts' Forecast Accuracy is -0.123 . This value is slightly lower than the mean of -0.071 shown in Shon and Shin (2014), but it is quite similar to the mean of -0.103 shown in Lim and Jung (2012). It suggests that the mean price-scaled absolute analysts' forecast error is 0.123 . The mean value of Analysts' Forecast Optimism shows 0.009, indicating that analysts have a tendency to forecast optimistically (Shon \& Shin, 2014). Especially notable are the mean and median values for Stock Recommendation: 2.703 and 3.000, respectively. This means that analysts' most frequently expressed recommendation regarding stocks is "Buy" (coded as 3), showing an optimistic bias in stock recommendation (Abarbanell, et al. 1995; McNichols \& O’Brien, 1997; Lim \& Jung, 2012). The mean HHI of 0.191 is similar to that reported by Shon and Shin (2014). Other control variables are shown to have similar patterns to those in the research of Lim and Jung (2012). 
The second and third columns of Table 3 document the descriptive statistics for the subsamples partitioned by the degree of product market competition. In both cases, each value of Relative Analysts' Forecast Accuracy and Absolute Analysts' Forecast Accuracy reveals higher accuracy in the high competition sample, as indicated by the mean values of 48.010 and -0.117 , respectively, for the high competition sample, and mean values of 47.982 and -0.129 , respectively, for the low competition sample. However, the results of the difference test are only partially significant. It seems that Analysts' Forecast Optimism is not affected by product market competition. As expected, there are significant differences in the Stock Recommendation measure between high and low competition samples. In the high competition sample, stock recommendations are more optimistic than in the low competition sample. These outcomes suggest that product market competition deteriorates analysts' information environments. As for the control variables, the difference tests for the variables between the two subsamples represent that the mean values for Firm size, Career experience, Firm-specific experience, Firm coverage, Industry coverage, and Broker size are significantly higher for firms in high competition markets, whereas those for Forecast horizon and Analyst following are higher for firms in low competition markets.

Table 3. Descriptive Statistics

\begin{tabular}{|c|c|c|c|c|c|c|}
\hline \multirow{3}{*}{ Variables } & & & & & & \\
\hline & \multicolumn{2}{|c|}{$\begin{array}{c}\text { Total } \\
\left(\mathbf{N}^{\#}=\mathbf{7 6 , 6 2 1}\right)\end{array}$} & \multicolumn{2}{|c|}{$\begin{array}{c}\text { Dummy for } H H I=1 \\
\left(\mathbf{N}^{\#}=38,296\right)\end{array}$} & \multicolumn{2}{|c|}{$\begin{array}{c}\text { Dummy for } H H I=0 \\
\left(\mathbf{N}^{\#}=38,325\right)\end{array}$} \\
\hline & Mean & Median & Mean & Median & Mean & Median \\
\hline Relative Analysts' Forecast Accuracy & 47.996 & 50.000 & 48.010 & 50.000 & 47.982 & 50.000 \\
\hline Absolute Analysts' Forecast Accuracy & -0.123 & -0.037 & -0.117 & -0.036 & -0.129 & -0.037 \\
\hline Analysts' Forecast Optimism & 0.009 & 0.090 & 0.003 & 0.092 & 0.014 & 0.088 \\
\hline Stock Recommendation & 2.703 & 3.000 & 2.709 & 3.000 & 2.697 & 3.000 \\
\hline$H H I$ & 0.191 & 0.185 & 0.098 & 0.092 & 0.284 & 0.281 \\
\hline Firm size & 13.075 & 12.966 & 13.100 & 13.144 & 13.050 & 12.793 \\
\hline Career experience & 3.889 & 3.000 & 3.985 & 3.000 & 3.792 & 3.000 \\
\hline Firm-specific experience & 1.886 & 1.000 & 1.969 & 1.000 & 1.804 & 1.000 \\
\hline Forecast horizon & 1.078 & 1.000 & 1.060 & 1.000 & 1.096 & 1.000 \\
\hline Firm coverage & 13.749 & 12.000 & 13.787 & 12.000 & 13.711 & 12.000 \\
\hline Industry coverage & 2.654 & 2.000 & 2.673 & 2.000 & 2.634 & 2.000 \\
\hline Broker size & 23.780 & 22.000 & 24.115 & 23.000 & 23.446 & 22.000 \\
\hline Analyst following & 17.218 & 17.000 & 15.843 & 16.000 & 18.592 & 18.000 \\
\hline
\end{tabular}

Panel B

\begin{tabular}{l|r|r|r}
\multicolumn{1}{c}{ Variables } & \multicolumn{2}{c}{ Difference } & $(\mathbf{( z - s t a t )}$ \\
\hline Relative Analysts' Forecast Accuracy & $\mathbf{1 - 0}$ & $(0.12)$ & $(-0.09)$ \\
\hline Absolute Analysts' Forecast Accuracy & 0.028 & $(6.06)$ & $(-0.30)$ \\
\hline Analysts' Forecast Optimism & 0.012 & $(-1.63)$ & $(-0.81)$ \\
\hline Stock Recommendation & -0.011 & $(3.05)$ & $(3.11)$ \\
\hline HHI & 0.011 & $(-401.04)$ & $(-239.72)$ \\
\hline Firm size & -0.186 & $(3.93)$ & $(9.06)$ \\
\hline Career experience & 0.051 & $(8.42)$ & $(10.27)$ \\
\hline Firm-specific experience & 0.193 & $(9.66)$ & $(-5.84)$ \\
\hline Forecast horizon & 0.165 & $(-5.08)$ & $(5.90)$ \\
\hline Firm coverage & -0.036 & $(1.32)$ & $(4.66)$ \\
\hline Industry coverage & 0.076 & $(3.76)$ & $(11.86)$ \\
\hline Broker size & 0.040 & $(9.35)$ & $(-34.71)$ \\
\hline Analyst following & 0.669 & $(-39.17)$ & \\
\hline
\end{tabular}

Notes: \#indicates that the numbers of observations for Optimism in the whole sample, the subsample with $\mathrm{HHI}=1$, and the subsample with $\mathrm{HHI}=$ 0 are 76,512, 38,224, and 38,228, respectively. The t-statistics and z-statistics in parentheses are obtained from the t-test and Wilcoxon rank sum test, respectively. ${ }^{* * *}$ indicates significance at the $1 \%$ level, $* *$ at the $5 \%$ level, and $*$ at the $10 \%$ level.

Table 4 presents the results of Pearson and Spearman correlations. The correlations between the Dummy for HHI and Relative Analysts' Forecast Accuracy are significantly positive. The correlations between the Dummy for HHI and 
Absolute Analysts' Forecast Accuracy are significant and negative. In addition, the correlations between the Dummy for HHI and Stock Recommendation are significant and positive.

\begin{tabular}{|c|c|c|c|c|c|c|c|c|}
\hline & & & & & & & & \\
\hline No. & Variables $\left(\mathrm{N}^{\#}=76,621\right)$ & 1 & 2 & 3 & 4 & 5 & 6 & 7 \\
\hline \multirow{2}{*}{1} & \multirow{2}{*}{ Relative Forecast Accuracy } & & 0.21 & -0.13 & -0.09 & 0.00 & -0.03 & 0.06 \\
\hline & & & $(0.00)$ & $(0.00)$ & $(0.00)$ & $(0.43)$ & $(0.00)$ & $(0.00)$ \\
\hline \multirow{2}{*}{2} & \multirow{2}{*}{ Absolute Forecast Accuracy } & 0.56 & & -0.11 & 0.09 & -0.04 & 0.31 & 0.12 \\
\hline & & $(0.00)$ & & $(0.00)$ & $(0.00)$ & $(0.00)$ & $(0.00)$ & $(0.00)$ \\
\hline \multirow{2}{*}{3} & \multirow{2}{*}{ Optimism } & -0.18 & -0.07 & & 0.11 & 0.00 & 0.01 & -0.06 \\
\hline & & $(0.00)$ & $(0.00)$ & & $(0.00)$ & $(0.30)$ & $(0.04)$ & $(0.00)$ \\
\hline \multirow{2}{*}{4} & \multirow{2}{*}{ Recommendation } & -0.09 & 0.08 & 0.13 & & 0.01 & 0.12 & 0.09 \\
\hline & & $(0.00)$ & $(0.00)$ & $(0.00)$ & & $(0.00)$ & $(0.00)$ & $(0.00)$ \\
\hline \multirow{2}{*}{5} & \multirow{2}{*}{ Dummy for $H H I$} & 0.00 & -0.01 & -0.01 & 0.01 & & 0.00 & -0.02 \\
\hline & & $(0.20)$ & $(0.00)$ & $(0.00)$ & $(0.01)$ & & $(0.35)$ & $(0.00)$ \\
\hline \multirow{2}{*}{6} & \multirow{2}{*}{ Firm size } & -0.02 & 0.35 & 0.01 & 0.11 & 0.00 & & 0.33 \\
\hline & & $(0.00)$ & $(0.00)$ & $(0.00)$ & $(0.00)$ & $(0.49)$ & & $(0.00)$ \\
\hline \multirow{2}{*}{7} & \multirow{2}{*}{ Career experience } & 0.06 & 0.18 & -0.07 & 0.07 & -0.01 & 0.33 & \\
\hline & & $(0.00)$ & $(0.00)$ & $(0.00)$ & $(0.00)$ & $(0.03)$ & $(0.00)$ & \\
\hline \multirow{2}{*}{8} & \multirow{2}{*}{ Firm-specific experience } & 0.12 & 0.20 & -0.09 & -0.04 & -0.02 & 0.34 & 0.61 \\
\hline & & $(0.00)$ & $(0.00)$ & $(0.00)$ & $(0.00)$ & $(0.00)$ & $(0.00)$ & $(0.00)$ \\
\hline \multirow{2}{*}{9} & \multirow{2}{*}{ Forecast horizon } & -0.28 & -0.43 & 0.29 & -0.04 & 0.02 & -0.22 & -0.18 \\
\hline & & $(0.00)$ & $(0.00)$ & $(0.00)$ & $(0.00)$ & $(0.00)$ & $(0.00)$ & $(0.00)$ \\
\hline \multirow{2}{*}{10} & \multirow{2}{*}{ Firm coverage } & 0.04 & -0.08 & -0.04 & -0.15 & -0.03 & -0.27 & 0.02 \\
\hline & & $(0.00)$ & $(0.00)$ & $(0.00)$ & $(0.00)$ & $(0.00)$ & $(0.00)$ & $(0.00)$ \\
\hline \multirow{2}{*}{11} & \multirow{2}{*}{ Industry coverage } & 0.01 & -0.04 & -0.01 & -0.11 & -0.04 & -0.23 & -0.11 \\
\hline & & $(0.01)$ & $(0.00)$ & $(0.02)$ & $(0.00)$ & $(0.00)$ & $(0.00)$ & $(0.00)$ \\
\hline \multirow{2}{*}{12} & \multirow{2}{*}{ Broker size } & -0.01 & -0.05 & -0.04 & -0.12 & -0.04 & -0.07 & 0.00 \\
\hline & & $(0.02)$ & $(0.00)$ & $(0.00)$ & $(0.00)$ & $(0.00)$ & $(0.00)$ & $(0.73)$ \\
\hline \multirow{2}{*}{13} & \multirow{2}{*}{ Analyst following } & -0.04 & 0.23 & 0.06 & 0.03 & 0.12 & 0.61 & 0.07 \\
\hline & & $(0.00)$ & $(0.00)$ & $(0.00)$ & $(0.00)$ & $(0.00)$ & $(0.00)$ & $(0.00)$ \\
\hline
\end{tabular}

(Table 4 continued on next page) 


\begin{tabular}{|c|c|c|c|c|c|c|c|}
\hline No. & Variables $\left(N^{\#}=76,621\right)$ & 8 & 9 & 10 & 11 & 12 & 13 \\
\hline \multirow{2}{*}{1} & \multirow{2}{*}{ Relative Forecast Accuracy } & 0.08 & -0.28 & 0.02 & 0.01 & -0.02 & -0.04 \\
\hline & & $(0.00)$ & $(0.00)$ & $(0.00)$ & $(0.09)$ & $(0.00)$ & $(0.00)$ \\
\hline \multirow{2}{*}{2} & \multirow{2}{*}{ Absolute Forecast Accuracy } & 0.11 & -0.26 & -0.06 & -0.06 & -0.06 & 0.17 \\
\hline & & $(0.00)$ & $(0.00)$ & $(0.00)$ & $(0.00)$ & $(0.00)$ & $(0.00)$ \\
\hline \multirow{2}{*}{3} & \multirow{2}{*}{ Optimism } & -0.07 & 0.29 & -0.06 & -0.01 & -0.03 & 0.06 \\
\hline & & $(0.00)$ & $(0.00)$ & $(0.00)$ & $(0.00)$ & $(0.00)$ & $(0.00)$ \\
\hline \multirow{2}{*}{4} & \multirow{2}{*}{ Recommendation } & 0.01 & -0.04 & -0.14 & -0.11 & -0.15 & 0.04 \\
\hline & & $(0.00)$ & $(0.00)$ & $(0.00)$ & $(0.00)$ & $(0.00)$ & $(0.00)$ \\
\hline \multirow{2}{*}{5} & \multirow{2}{*}{ Dummy for HHI } & -0.02 & 0.02 & -0.02 & -0.01 & -0.03 & 0.11 \\
\hline & & $(0.00)$ & $(0.00)$ & $(0.00)$ & $(0.08)$ & $(0.00)$ & $(0.00)$ \\
\hline \multirow[b]{2}{*}{6} & \multirow[b]{2}{*}{ Firm size } & 0.34 & -0.20 & -0.25 & -0.23 & -0.10 & 0.61 \\
\hline & & $(0.00)$ & $(0.00)$ & $(0.00)$ & $(0.00)$ & $(0.00)$ & $(0.00)$ \\
\hline \multirow{2}{*}{7} & \multirow{2}{*}{ Career experience } & 0.65 & -0.15 of the & -0.05 & -0.12 & -0.05 & 0.06 \\
\hline & & $(0.00)$ & $(0.00)$ & $(0.00)$ & $(0.00)$ & $(0.00)$ & $(0.00)$ \\
\hline \multirow{2}{*}{8} & \multirow{2}{*}{ Firm-specific experience } & & -0.19 & -0.08 & -0.12 & 0.00 & 0.16 \\
\hline & & & $(0.00)$ & $(0.00)$ & $(0.00)$ & $(0.67)$ & $(0.00)$ \\
\hline \multirow{2}{*}{9} & \multirow{2}{*}{ Forecast horizon } & -0.27 & & 0.02 & 0.06 & 0.03 & -0.16 \\
\hline & & $(0.00)$ & & $(0.00)$ & $(0.00)$ & $(0.00)$ & $(0.00)$ \\
\hline \multirow{2}{*}{10} & \multirow{2}{*}{ Firm coverage } & -0.03 & 0.02 & & 0.51 & 0.02 & -0.10 \\
\hline & & $(0.00)$ & $(0.00)$ & & $(0.00)$ & $(0.00)$ & $(0.00)$ \\
\hline \multirow{2}{*}{11} & \multirow{2}{*}{ Industry coverage } & -0.11 & 0.07 & 0.46 & & 0.05 & -0.14 \\
\hline & & $(0.00)$ & $(0.00)$ & $(0.00)$ & & $(0.00)$ & $(0.00)$ \\
\hline \multirow{2}{*}{12} & \multirow{2}{*}{ Broker size } & 0.05 & 0.01 & -0.01 & 0.05 & & -0.08 \\
\hline & & $(0.00)$ & $(0.07)$ & $(0.03)$ & $(0.00)$ & & $(0.00)$ \\
\hline \multirow{2}{*}{13} & \multirow{2}{*}{ Analyst following } & 0.20 & -0.18 & -0.11 & -0.15 & -0.09 & \\
\hline & & $(0.00)$ & $(0.00)$ & $(0.00)$ & $(0.00)$ & $(0.00)$ & \\
\hline
\end{tabular}

Notes: This table presents the Pearson (above the diagonal) and Spearman (below the diagonal) correlations among the variables. P-values are in parentheses

\section{Testing of Hypothesis 1}

Panel A of Table 5 shows the results for the multivariate tests of Hypothesis 1 based on the dependent variable of Absolute Analysts' Forecast Accuracy. In model 1 of Panel A, which presents the OLS results, the coefficient of the Dummy for $\mathrm{HHI}$ is positive and significant at the $1 \%$ level, after controlling for the various determinants of analysts' forecast accuracy. This result is consistent with that competition plays an external governance mechanism in improving analysts' information environments (Shon \& Shin, 2014). However, Model 2 of Panel A finds the opposite result, demonstrating the limitations of the absolute analysts' forecast accuracy measure utilized in prior studies. The results in the Fama-MacBeth regressions document the positive coefficient for the Dummy for HHI, but it is nonsignificant after eliminating the yearly correlations among the variables. These results suggest several important things. The Fama-MacBeth estimation (Fama \& MacBeth, 1973) addresses the potential bias issue caused by crosssectional dependencies in panel data. It entails calculation of the mean values of the yearly coefficients and the tvalues by using the standard errors of the time-series of the yearly estimates. ${ }^{1}$ For this reason, the results of Model 1 may have typical endogeneity problems (Lim \& Jung, 2012). Put differently, although absolute analysts' forecast accuracy is a function of time, the fact that it occurs so frequently in highly competitive industries seems to indicate that high competition increases absolute analysts' forecast accuracy. Thus, we can conclude that restricting the

\footnotetext{
${ }^{1}$ Following Lim and Jung (2012), we estimate the regressions for each of the 15 calendar years separately. Next, we compute the mean value of the coefficients across the 15 years and calculate t-statistics for the mean coefficients by using the standard deviation of the estimates for a year. The specific equation of Fama-MacBeth t-statistics are as follows:

where the mean (coefficient) $=\frac{1}{15} \sum_{i=2000}^{2014}$ coefficient $_{i}$ $t-$ stat. (coefficient) $=\frac{\text { mean (coefficient) }}{\sqrt{\frac{1}{15} \operatorname{var}(\text { coefficient })}}$ $\operatorname{var}($ coefficient $)=\frac{1}{14} \sum_{i=2000}^{2014}\left[\text { coefficient }_{i}-\text { mean (coefficient) }\right]^{2}$.
} 
measurement of absolute analysts' forecast accuracy does not support our hypothesis. Thus, we move to the next analysis.

Panel B presents the association between Relative Analysts' Forecast Accuracy and the Dummy for HHI. In Model 1 of Panel B, the coefficient of the Dummy for HHI is -0.910 , which shows significance at the $1 \%$ level. Model 2 of Panel B is a result from using the Fama-MacBeth method. Similarly, the coefficient for the Dummy for HHI is significantly negative at the $1 \%$ level, indicating that analysts' forecasts in highly competitive product markets show less accuracy compared to those in less competitive industries after controlling for the potential endogeneity problem. The results of the regression analysis also show that Firm size, Firm-specific experience, Forecast horizon, and Analyst following reduce Relative Analysts' Forecast Accuracy, and Firm-specific experience and Firm coverage increase it. In summary, Hypothesis 1 is supported.

Table 5. Analysts' Forecast Accuracy

\begin{tabular}{|c|c|c|c|c|c|}
\hline \multicolumn{6}{|c|}{ Panel A. Absolute Analysts' Forecast Accuracy } \\
\hline \multirow{2}{*}{$\begin{array}{l}\text { Variables } \\
\text { Intercept }\end{array}$} & \multirow[t]{2}{*}{$\begin{array}{l}\text { Predicted } \\
\text { sign }\end{array}$} & \multicolumn{2}{|c|}{$\begin{array}{c}\text { Model } 1 \\
\text { (OLS) }\end{array}$} & \multicolumn{2}{|c|}{$\begin{array}{c}\text { Model 2 } \\
\text { (Fama-MacBeth) }\end{array}$} \\
\hline & & -0.609 & $(-66.43)^{* * *}$ & -0.595 & $(-8.08)^{* * *}$ \\
\hline Dummy for $H H I$ & $+/-$ & 0.005 & $(2.72)^{* * *}$ & 0.004 & $(0.67)$ \\
\hline Firm size & + & 0.044 & $(62.07)^{* * *}$ & 0.042 & $(6.36)^{* * *}$ \\
\hline Career experience & - & 0.001 & $(1.17)$ & 0.001 & $(0.93)$ \\
\hline Firm-specific experience & + & -0.003 & $(-5.06)^{* * *}$ & -0.007 & $(-1.81)^{*}$ \\
\hline Forecast horizon & - & -0.058 & $(-61.75)^{* * *}$ & -0.058 & $(-6.03)^{* * *}$ \\
\hline Firm coverage & $+/-$ & 0.000 & $(0.20)$ & 0.000 & $(0.67)$ \\
\hline Industry coverage & - & 0.003 & $(4.58)^{* * *}$ & 0.003 & $(1.65)$ \\
\hline Broker size & + & -0.001 & $(-9.96)^{* * *}$ & 0.000 & $(-3.90)^{* * *}$ \\
\hline Analyst following & & -0.001 & $(-9.60)^{* * *}$ & -0.001 & $(-0.97)$ \\
\hline $\mathrm{R}^{2}$ & & \multicolumn{2}{|c|}{0.139} & & \\
\hline \# of observations & & \multicolumn{2}{|c|}{76,621} & \multicolumn{2}{|c|}{76,621} \\
\hline
\end{tabular}

Panel B. Relative Analysts' Forecast Accuracy

\begin{tabular}{|c|c|c|c|c|c|}
\hline \multirow{2}{*}{ Intercept } & \multirow[t]{2}{*}{$\begin{array}{l}\text { Predicted } \\
\text { sign }\end{array}$} & \multicolumn{2}{|c|}{$\begin{array}{l}\text { Model } 1 \\
\text { (OLS) }\end{array}$} & \multicolumn{2}{|c|}{$\begin{array}{c}\text { Model 2 } \\
\text { (Fama-MacBeth) }\end{array}$} \\
\hline & & 77.788 & $(67.46)^{* * *}$ & 76.535 & $(16.59)^{* * *}$ \\
\hline Dummy for HHI & $+/-$ & -0.910 & $(-3.96)^{* * *}$ & -1.097 & $(-3.59)^{* * *}$ \\
\hline Firm size & + & -1.209 & $(-13.42)^{* * *}$ & -1.080 & $(-4.09)^{* * *}$ \\
\hline Career experience & - & -0.039 & $(-0.81)$ & -0.099 & $(-0.46)$ \\
\hline Firm-specific experience & + & 0.856 & $(13.25)^{* * *}$ & 1.370 & $(4.77)^{* * *}$ \\
\hline Forecast horizon & - & -9.691 & $(-81.75)^{* * *}$ & -11.634 & $(-6.80)^{* * *}$ \\
\hline Firm coverage & $+/-$ & 0.001 & $(0.03)$ & 0.047 & $(1.78)^{*}$ \\
\hline Industry coverage & - & 0.202 & $(2.23)^{* *}$ & 0.114 & $(1.65)$ \\
\hline Broker size & + & -0.068 & $(-5.94)^{* * *}$ & -0.017 & $(-0.57)$ \\
\hline Analyst following & & -0.201 & $(-13.26)^{* * *}$ & -0.250 & $(-4.65)^{* * *}$ \\
\hline $\mathrm{R}^{2}$ & & \multicolumn{2}{|c|}{0.091} & & \\
\hline \# of observations & & \multicolumn{2}{|c|}{76,621} & \multicolumn{2}{|c|}{76,621} \\
\hline
\end{tabular}

\section{Testing of Hypothesis 2}

Applying the model in Cowen et al. (2006), we conduct a multivariate regression to test $\mathrm{H} 2$ which investigates the association between product market competition and optimism in analysts' forecasts. In Table 6, the OLS coefficient for the Dummy for HHI in Model 1 is 0.030 at the $1 \%$ significance level. It suggests that analysts tend to report more optimistic EPS forecasts for firms within highly competitive product markets. The results in Model 2 provide qualitatively similar results to those in Model 1 and also support the idea of analysts' forecast optimism in competitive markets. Specifically, the coefficient of the Dummy for HHI using the Fama-MacBeth method is significantly positive 
at the $1 \%$ level. These results suggest that as information asymmetry due to competition deteriorates information environment of firms, analysts are likely to report more optimistic forecasts to curry favor with managers and gain firm-specific non-public information (Huberts \& Fuller, 1995; Ackert \& Athanassakos, 1997; Das et al., 1998; Lim, 2001). Overall, Hypothesis 2 is supported.

Table 6. Analysts' Forecast Optimism

\begin{tabular}{|c|c|c|c|c|}
\hline Variables & \multicolumn{2}{|c|}{$\begin{array}{l}\text { Model } 1 \\
\text { (OLS) }\end{array}$} & \multicolumn{2}{|c|}{$\begin{array}{c}\text { Model 2 } \\
\text { (Fama-MacBeth) }\end{array}$} \\
\hline Intercept & -0.310 & $(-9.51)^{* * *}$ & -0.383 & $(-3.50)^{* * *}$ \\
\hline Dummy for $H H I$ & 0.030 & $(4.65)^{* * *}$ & 0.030 & $(4.20)^{* * *}$ \\
\hline Firm size & -0.001 & $(-0.26)$ & 0.001 & $(0.24)$ \\
\hline Career experience & -0.004 & $(-2.98)^{* * *}$ & 0.009 & $(0.85)$ \\
\hline Firm-specific experience & -0.008 & $(-4.37)^{* * *}$ & -0.003 & $(-0.33)$ \\
\hline Forecast horizon & 0.283 & $(84.33)^{* * *}$ & 0.306 & $(8.09)^{* * *}$ \\
\hline Firm coverage & -0.008 & $(-15.71)^{* * *}$ & -0.006 & $(-4.31)^{* * *}$ \\
\hline Industry coverage & 0.009 & $(3.69)^{* * *}$ & 0.010 & $(2.40)^{* *}$ \\
\hline Broker size & -0.002 & $(-7.29)^{* * *}$ & -0.002 & $(-1.99)^{*}$ \\
\hline Analyst following & 0.010 & $(23.32)^{* * *}$ & 0.009 & $(7.89)^{* * *}$ \\
\hline $\mathrm{R}^{2}$ & \multicolumn{2}{|c|}{0.098} & & \\
\hline \# of observations & \multicolumn{2}{|c|}{76,512} & \multicolumn{2}{|c|}{76,512} \\
\hline
\end{tabular}

Notes: The t-statistics are in parentheses. Standard errors are corrected for firm-level clustering. ${ }^{*},{ }^{*}$, and ${ }^{* * *}$ denote significance levels (twosided) of $10 \%, 5 \%$, and $1 \%$, respectively.

\section{Testing of Hypothesis 3}

Table 7 reports the results of the multivariate test of Hypothesis 3 by using stock recommendations for the dependent variable. Column 2 presents the results using an ordered logit regression and Column 3 reports the results using the Fama-MacBeth method. Ordered logit regression is used to consider the discrete and ordinal nature of stock recommendations (Cowen et al., 2006; Kolasinski \& Kothari, 2008). As a result, the coefficient of the Dummy for $H H I$ in Model 1 is 0.038 with significance at the 5\% level, suggesting that analysts express significantly higher optimism in their stock recommendations in competitive markets. Model 2 of Table 7 indicates that the coefficient of the Dummy for HHI is 0.054 , which is also significant and positive. These results suggest that since high competition causes managers to withhold firm-specific information in order to protect companies from their rivals, analysts may provide more optimistic stock recommendations to promote investment banking business and to increase trading commissions through maintaining close relationships with managers in pursuit of information (Francis et al., 1997; Lin \& McNichols, 1998; Irvine, 2004). In summary, all of the results reported in Table 7 provide further support for the assertion that product market competition negatively affects analysts' information environments, which discourages proper assessment of stock valuation.

Table 7. Stock Recommendation Optimism

\begin{tabular}{|c|c|c|c|c|}
\hline Variables & \multicolumn{2}{|c|}{ Model 1} & \multicolumn{2}{|c|}{ Model 2} \\
\hline Dummy for $H H I$ & 0.038 & $(2.40)^{* *}$ & 0.054 & $(3.27)^{* * *}$ \\
\hline Career experience & 0.107 & $(28.99)^{* *}$ & 0.107 & $(28.32)^{* * *}$ \\
\hline Firm-specific experience & -0.101 & $(-21.28)^{* * *}$ & -0.082 & $(-16.74)^{* * *}$ \\
\hline Forecast horizon & -0.040 & $(-4.77)^{* * *}$ & -0.043 & $(-4.97)^{* * *}$ \\
\hline Relative forecast accuracy & 0.547 & $(19.18)^{* * *}$ & 0.645 & $(21.80)^{* * *}$ \\
\hline Number of strong buy & & & 0.459 & $(16.17)^{* * *}$ \\
\hline Number of buy & & & -0.037 & $(-36.21)^{* * *}$ \\
\hline Number of hold & & & -0.389 & $(-65.62)^{* * *}$ \\
\hline Number of underperform & & & -2.632 & $(-26.80)^{* * *}$ \\
\hline Number of sell & & & -19.273 & $(-0.27)$ \\
\hline $\mathrm{R}^{2}$ & \multicolumn{2}{|c|}{0.019} & \multicolumn{2}{|c|}{0.115} \\
\hline \# of observations & \multicolumn{2}{|c|}{76,621} & \multicolumn{2}{|c|}{76,621} \\
\hline
\end{tabular}

Notes: The t-statistics are in parentheses. Standard errors are corrected for firm-level clustering. ${ }^{*}, * *$, and ${ }^{* * *}$ denote significance levels (twosided) of $10 \%, 5 \%$, and $1 \%$, respectively. 


\section{SUMMARY AND CONCLUSIONS}

In this study, we investigate the association between product market competition and analysts' forecasting properties by using analysts' forecast accuracy, analysts' forecast bias, and optimism in stock recommendations. We find that firms in more competitive product markets have less informative disclosure environments, as evidenced by following analysts' forecasting properties.

First, our results suggest that absolute analysts' forecast accuracy is positively related to product market competition; however, these effects disappear after estimating absolute analysts' forecast accuracy using the Fama-MacBeth regressions (Fama \& MacBeth, 1973). These findings are robust to the potential bias issue caused by cross-sectional dependencies in the panel data. Next, by using a more sophisticated measure of relative analysts' forecast accuracy we find that product market competition is negatively associated with relative analysts' forecast accuracy. Since the measure of relative analysts' forecast accuracy takes into account analysts' performance compared to their peers, our findings conclude that high competition in product markets is likely to decrease accuracy in analysts' forecast (Hong \& Kubik, 2003; Cowen et al., 2006). Second, in terms of forecast bias, high competition in product markets is related to analysts' forecast optimism. These findings suggest that optimism in analysts' forecasts increases with information complexity due to competition in predicting earnings information. Under such circumstances, analysts' forecasts are shown to have more optimism in order to curry favor with managers in gaining relevant information about the firm (Huberts \& Fuller, 1995; Ackert \& Athanassakos, 1997; Das et al., 1998; Lim, 2001). Finally, we find a positive association between high competition and optimism in analysts' stock recommendations. These findings suggest that firms in highly competitive markets are less likely to disclose firm-specific information, resulting in inferior information environments for the competitive markets.

Overall, the evidence provided in this study is consistent with the findings in extant accounting and finance literature, which shows a negative effect of product market competition on corporate information environment as measured by analysts' forecasting properties such as analysts' forecast accuracy, bias, and optimism in stock recommendations.

\section{ACKNOWLEDGEMENT}

This Research was supported by the Chung-Ang University Research Grants in 2017

\section{AUTHOR BIOGRAPHIES}

Ms. Lee is an assistant professor of Accounting at Sangmyung University. She graduated from Yonsei University.

Mr. Mo is an assistant professor of Accounting at Chung-Ang University. He graduated from Korea Advanced Institute of Science and Technology.

\section{REFERENCES}

Abarbanell, S., Lanen, N., \& Verrecchia, R. E. (1995). Analysts' forecasts as proxies for investor beliefs in empirical research. Journal of Accounting and Economics, 20, 31-60.

Ackert, L. F., \& Athanassakos, G. (1997). Prior uncertainty, analyst bias, and subsequent abnormal returns. The Journal of Financial Research, 10, 263-273.

Ali, A., Klasa, S., \& Yeung, E. (2009). The limitations of industry concentration measures constructed with Compustat data: implications for finance research. Review of Financial Studies, 22(10), 3839-3871.

Allen, F., \& D. Gale. (2000). Corporate governance and competition. Corporate Governance: Theoretical and empirical perspective. Cambridge University Press, 23-94.

Bae, K. H., Stulz, R. M., \& Tan. H. (2008). Do local analysts know more? A cross-country study of the performance of local analysts and foreign analysts. Journal of Financial Economics, 88(3), 581-606.

Baggs, J., \& Bettignies, J. (2007). Product market competition and agency costs. Journal of Industrial Economics, 55(2), 289323.

Barniv, R., Myring, M. J., \& Thomas. W. B. (2005). The association between the legal and financial reporting environments and forecast performance of individual analysts. Contemporary Accounting Research, 22(4), 727-758. 
Barth, M., Landsman, W. \& Rendleman. R. (1998). Option Pricing-based Bond Value Estimates and a Fundamental Components Approach to Account for Corporate Debt. The Accounting Review, January: 73-102.

Berger, P. G. (2011). Challenges \& opportunities in disclosure research - A discussion of 'the financial reporting environment: Review of the recent literature.' Journal of Accounting and Economics, 51, 204-218.

Beyer, A., Cohen, D., Lys, T., \& Walther, B. (2010). The financial reporting environment: Review of the recent literature. Journal of Accounting and Economics, 50, 296-343.

Bidwell, C. (1977). How Good is Institutional Brokerage Research? Journal of Portfolio Management, 3, $393-416$.

Brown, L. D. (1993). Earnings forecasting research: its implications for capital market research. International Journal of Forecasting, 9, 295-320.

Cheng, P., Man, P., \& Yi, C. (2013). The impact of product market competition on earnings quality. Accounting and Finance, 53(1), 137-162.

Clement, M. (1999). Analyst forecast accuracy: Do ability, resources, and portfolio complexity matter? Journal of Accounting and Economics, 27(3), 285-304.

Clinch, G., \& Verrecchia, R. E. (1997). Competitive disadvantage and discretionary disclosure in industries. Australian Journal of Management, 22, 125-137.

Cowen, A., Groysberg, B. \& Healy, P. (2006). Which types of analyst firms are more optimistic? Journal of Accounting and Economics, 41(1-2), 119-146.

Cowles, A. (1933). Can Stock Market Forecasters Forecast? Econometrica, 1, 309-324.

Darrough, M. N., \& Stoughton, N. M. (1990). Financial disclosure policy in an entry game. Journal of Accounting and Economics, 12, 219-243.

Das, S., Levine, C., \& Sivaramakrishnan, K. (1998). Earnings predictability and bias in analysts' earnings forecasts. The Accounting Review, 73, 277-294.

DeFond, M., \& Park, C. (1999). The effect of competition on CEO turnover. Journal of Accounting and Economics, 27(1), 35-56.

Dhaliwal, D., Huang, S., Khurana, I., \& Pereira, R. (2012). Product market competition and accounting conservatism. Working paper, University of Arizona, University of Arkansas, and University of Missouri at Columbia.

Fama, G., \& MacBeth, J. (1973). Risk, return and equilibrium: Empirical tests. Journal of Political Economy, 81(3), 607-637.

Feriozzi, F. (2011). Paying for observable luck. RAND Journal of Economics, 42(2), 387-415.

Francis, J., Hanna, D., \& Philbrick, D. (1997). Management communications with securities analysts. Journal of Accounting and Economics, 24, 363-394.

Gaspar, J. M. \& Massa, M. (2006). Idiosyncratic volatility and product market competition. Journal of Business, 79, 3125-3152.

Gertner, R., Gibbons, R., \& Scharfstein, D. (1988). Simultaneous signaling to the capital and product markets. RAND Journal of Economics, 19, 173-190.

Giroud, X., \& Mueller, H. M. (2010). Does corporate governance matter in competitive industries? Journal of Financial Economics, 95, 312-331.

Grossman, S. J. (1981). The role of warranties and private disclosure about product quality. Journal of Law and Economics, 24, 461-483.

Gu, Z., \& J. Xue. (2008). The superiority and disciplining role of independent analysts. Journal of Accounting and Economics, 45(2-3), 289-316.

Harris, M. S. (1998). The association between competition and managers' business segment reporting decisions. Journal of Accounting Research, 36, 111-128.

Hart, O. (1983). The market mechanism as an incentive scheme. Bell Journal of Economics, 14(2), 366-382.

Hayes, R., \& Lundholm, R. (1996). Segment reporting to the capital market in the presence of a competitor. Journal of Accounting Research, 34, 261-279.

Hayn, C. (1995). The information content of losses. Journal of Accounting \& Economics, 20, 125-153.

Hoberg, G., \& Phillips, G.M. (2010). Real and financial industry booms and busts. Journal of Finance, 65, 45-86.

Hong, H., \& Kubik, J. (2003). Analyzing the analysts: Career concerns and biased earnings forecasts. Journal of Finance, 58(1), 313-351.

Hong, H., J. D. Kubik, \& A. Solomon. (2000). Security analysts' career concerns and herding of earnings forecasts. RAND Journal of Economics, 31(1), 121-144.

Hou, K., \& Robinson, D. (2006). Industry concentration and average stock returns. Journal of Finance, 61(4), $1927-1956$.

Huberts, L. C., \& Fuller, R. J. (1995). Predictability bias in the U.S. equity market. Financial Analysts Journal, 51(2), 12-28.

Irvine, P. (2004). Analysts' forecasts and brokerage-firm trading. The Accounting Review, 79, 125-149.

Irvine, P., \& Pontiff, J. (2009). Idiosyncratic return volatility, cash flows, and product market competition. Review of Financial Studies, 22, 1149-1177.

Ivkovic, Z., \& Jegadeesh, N. (2004). The timing and value of forecast and recommendation revisions. Journal of Financial Economics, 73, 433-463.

Jacob, J., Lys, T., \& Neale, M. (1999). Expertise in forecasting performance of security analysts. Journal of Accounting and Economics, 28(1), 51-82.

Kolasinski, A., \& Kothari, S. P. (2008). Investment banking and analyst objectivity: Evidence from analysts' affiliated with M\&A advisors. Journal of Financial and Quantitative Economics, 43, 812-847. 
Laksmana, I., \& Yang, Y. W. (2012). Product market competition and earnings management: evidence from discretionary accruals and real activity manipulation. Working paper, Kent State University and Wake Forest University.

Li, F., Lundholm, R., \& Minnis, M. (2013). A Measure of Competition Based on 10-K Filings. Journal of Accounting Research, 51(2), 399-436.

Lim, T. (2001). Rationality and analysts' bias. Journal of Finance, 56, 369-385.

Lim, Y., \& Jung, K. (2012). Conflict of Interest or Information Sharing? Evidence from Affiliated Analyst Performance in Korea. Contemporary Accounting Research, 29(2), 505-537.

Lin, H. W., \& McNichols, M. (1998). Underwriting relationships, analysts' earnings forecasts, and investment recommendations. Journal of Accounting and Economics, 25(1), 101-127.

Loh, R. K., \& Mian, G. M. (2006). Do accurate earnings forecasts facilitate superior investment recommendations? Journal of Financial Economics, 80, 455-483.

Markarian, G., \& Santalo, J. (2014). Product Market Competition, Information and Earnings Management. Journal of Business Finance and Accounting, 41(5-6), 572-599.

McNichols, M., \& O'Brien, P. (1997). Self-selection and analyst coverage. Journal of Accounting Research, 35, $167-199$.

Meyer, M., \& Vickers, J. (1997). Performance comparisons and dynamic incentives. Journal of Political Economy, 105(3), 547581.

Mikhail, M. B., Walther, B. R., \& Willis, R. H. (1999). Does forecast accuracy matter to security analysts? The Accounting Review, 74, 185-200.

Milgrom, P. (1981). Good news and bad news: Representation theorems and applications. Bell Journal of Economics, 12, 380391.

Nickell, S. (1996). Competition and corporate performance. Journal of Political Economy, 104, 724-746.

Petersen, M. (2009). Estimating standard errors in finance panel data sets: comparing approaches. Review Financial Studies, 22, 435-480.

Schipper, K. (1991). Commentary on analysts' forecasts. Accounting Horizons, 5, 105-121.

Schmidt, K. (1997). Managerial incentives and product market competition. Review of Economic Studies, 64(219), 191-213.

Sohn, S. K., \& Shin, I. H. (2014). A Study on the Effect of Product Market Competition on Analyst Forecast. Korea Management Review, 43(4), 1029-1058. [Printed in Korean]

Stickel, S. (1992). Reputation and performance among security analysts. Journal of Finance, 47, 1811-1836.

Stickel, S. E. (1989). The timing of and incentives for annual earnings forecasts near interim earnings announcements. Journal of Accounting and Economics, 11(2-3), 275-293.

Stivers, A. E. (2004). Unraveling of information: competition and uncertainty. BE Journal of Theoretical Economics, 4, 1-30.

Verrecchia, R. (1983). Discretionary disclosure. Journal of Accounting and Economics, 5, 365-380.

Verrecchia, R. E., \& Weber, J. (2006). Redacted disclosure. Journal of Accounting Research, 44, 791-814.

Vickers, J. (1995). Concepts of competition. Oxford Economic Papers, 47(1), 1-23.

Wagenhofer, A. (1990). Voluntary disclosure with a strategic opponent. Journal of Accounting and Economics, 12, 341-363.

Womack, K. (1996). Do brokerage analysts' recommendations have investment value? Journal of Finance, 51, $137-167$. 


\section{NOTES}

